\title{
The Effect of Ghasab on Santri Success
}

\author{
S W Qur'ana \\ Islamic Building School of Jagad Alimussirry Surabaya, Indonesia \\ Email:qurana03@gmail.com
}

\begin{abstract}
This research is a case study, which is an intensive and detailed intensive study of a particular organization, institution or symptom. This type of research is field research, namely research in which data collection is carried out in the field. This research is a case study, which is an intensive and detailed intensive study of a particular organization, institution or symptom. Ghasab influences one's success, Allah Almighty has explained in the Qur'an that there are 9 keys to success namely Prayer (Al-Muttaqin, Al-Baqarah: 1-5, Luqman: 5), Forming Communities That Help Each Other Toward Success, Increase Positive Activities, Follow and emulate the Messenger of Allah, Fight and Exert all efforts, Obey Allah's Orders and Laws, share with relatives and relatives (Ar-rum 38), Stay Away from Miserability, Firmness Against Infidels.
\end{abstract}

Keywords: ghasab; success; santri

\section{INTRODUCTION}

The pesantren is like any other educational institution, in the body of the pesantren there are also various kinds of problems as the education process is being carried out. Problems in moral education become a common theme in this thesis. Pesantren is the oldest Islamic education institution in Indonesia. In Islamic boarding schools, there are usually clerics, there are students, there are activities to read the yellow book, and there are santri lodges, and there are mosques. In Islamic boarding schools students are taught to read the Koran, Islamic faith, fiqh (worship), and morals. The main subject matter is often called religious teaching material.

Pesantren which one of its roles and functions is to form human beings who have noble character and noble character, in fact there appears habits that are contrary to religion practiced by the students, the habit in question is the act of ghasab. Namely the act of using the property of others without the permission of the right. In fact, because these actions have often occurred, ghasab can be said to be an entrenched thing. Although in fact such cases do not only occur in pesantren circles.

In various educational institutions that use the boarding school system, dormitories, similar cases also often occur. The more concern is seeing the pesantren's roles, functions and responsibilities in its efforts to give birth to a generation of Muslims who have scientific and moral integrity. Having the habit of deviant behavior, namely the habit of doing ghasab. What is behind the emergence of such conditions. So, in this thesis an effective formula is offered to overcome these problems and how the influence of ghasab on the success of a santri. This is important because it can be from the habits of this ghasab that mental seeds of corruption emerge. Of course we all still remember what happened in the body of the Indonesian Ministry of Religion. As it turns out, corruption cases within the department that are 
filled with people with strong religious education backgrounds are included in the largest category in Indonesia, although not the largest.

\section{A. Understanding Ghasab}

Ghasab according to language is taking something (objects or goods) by way of wrongdoing openly. Whereas according to syara is controlling the rights of others through persecution. In the large Indonesian dictionary the word ghasab means unlawfully using the property of others for one's own interests. In the study of jurisprudence itself, there are several notions of ghasab put forward by ulama. First, according to the Maliki School of thought, ghasab is to take the property of another person by force and arbitration, not in the sense of robbing

Whereas the Hanafi school of scholars added the definition of ghasab to the phrase "openly" to distinguish it from theft, because theft was carried out secretly or in secret. But Hanafi scholars do not categorize in ghasab actions if they only take advantage of it.

The Shafi'ite scholars and the Madali Hambali have more general definitions than the two previous definitions. According to them ghasab is the control of other people's property arbitrarily or by force without rights. Ghasab does not only take material possessions but also benefits objects.

Of the three definitions above, what I use is a combination of the three. So ghasab is the control of the property of others arbitrarily or forcibly without rights, not in the sense of robbing or stealing, either taking material property or taking advantage of an object.

\section{B. The Emergence of Ghasab which Becomes Culture}

Regarding santri culture in the life of pesantren, there are certainly many. However, here will be explained a little about the culture of students in boarding schools including: a. Mujahadah, b. Pilgrimage, c. Community service (ro'an)
In addition to the culture or habits above, students in Islamic boarding schools have a unique habit of using something owned by other students as they wish. Each santri considers the objects and goods that are owned together, so that it can be used together. If there is one item or object that is needed immediately used, no matter who the owner is. This custom is known as ghasab.

In addition there are two important factors that give birth to these habits: First, because of the tendency of the heart for the action, he feels happy to do it, in other words he is attracted by these attitudes and actions. Although, maybe the act is not in accordance / violate existing norms. Second, the inclination of the heart's tendency to be repeated practice, so that it becomes normal.

How to change customs, according to ethics experts, among others by:

1. There must be firm intention and a strong will to replace old habits with new ones.

2. There must be confidence in the goodness of the new habit.

3. The existing resistance to old habits and the pull / impetus for new customs must always be turned on.

4. Must always use good opportunities to implement new customs.

5. Must try never to violate new habits.

\section{Santri Ethics}

Ethics is a theory of human behavior seen from good and bad values, as far as reason can be determined. Ethics are based on reason while morals are based on religion. Ahmad Amin argues that ethical issues are all actions that arise from people who commit intentionally and intentionally, and he knows when he did what he did. This is what we can give good and bad laws, as well as all actions that arise not with the will, but can be guarded while conscious, as for what arises not the will, and cannot be maintained before, then it is not from the main ethical issues. Demand to have good ethics towards the kiai or teacher, namely: Don't walk in front of him, don't sit in 
front of him, don't start a conversation unless with his permission, don't talk much in front of him, don't ask questions when tired.

\section{METHOD}

This type of research is field research, namely research in which data collection is carried out in the field. This research is a case study, which is an intensive and detailed intensive study of a particular organization, institution or symptom.

\section{RESULT AND DISCUSSION}

This result in this research is the students often use goods that do not belong to them in the pesantren environment without asking permission. Whether it's belonged to Islamic boarding school students themselves or guests. Usually the types of goods are small items that become daily necessities. For example footwear, toiletries, clothes, too book. If the owner of the goods is in the place, usually they just ask for permission. Or conversely, they use the goods without permission first, later when they meet the owner they ask for permission. But it reflects actions that are full of arbitrariness, and this is actually the main basis for the actions categorized ghasab.

Jurisprudence scholars agree that the ghasab's actions are forbidden and those who commit $\sin$. Whoever is in the form of assets, then he is obliged to return the property to its owner, even though he has to bear the burden of return (at a price) multiplied. This is based on the word of Allah Q.S Al-Baqarah: 188

In a hadith the law of ghasab is explained:

"From Sa'id bin Zaid r.a, indeed the Messenger of Allah. Say, whoever takes a piece of land wrongfully, Allah will drape the land on the Day of Judgment from the seven layers of the earth. (Muttafaq 'alaih)."

From the argument above it is clear that ghasab is forbidden by religion. Islam prohibits doing wrongdoing in any form. The culprit is a very severe threat of torture. And those who do ghasab must repent to Allah and return what he ghasab to their owner and apologize to him.

Ghasab can affects someone's success. Such as an idiom that the people who have stolen a needle at a pesantren, then tomorrow outside they have the potential to steal a cow, Hj. Ainun Hakiemah, head of Madrasah Aliyah Sunan Pandanaran, Sleman Yogyakarta.

The above statement is very relevant to the inculcation of character education in pesantren. Pesantren is one of the oldest and non-formal educational institutions which is popular among the people of Indonesia. Many great scholars have been printed from the foundation of a pesantren.

This, on the other hand, will erode some of the moral values in the pesantren. For example, in the case of ownership of an item (milkiyyah). Milkiyyah violations that often occur in Islamic boarding schools are ghosob (borrowing other people's goods without the permission of the owner) this behavior in the long run will develop into theft. This is what will reduce the quality of scholars in the present, they are in terms of scientific expertise, but less in terms of blessing.

In the book of Alaalaa, it is said that a person's character is influenced by people close to him. Without realizing it, actually ghosob culture is taught by these students themselves indirectly, hereditary.

The Indonesian state views the santri as the heirs of honest, just and anti-corruption leaders. Then what if the students themselves do not care about this milkiyyah problem. In this context the intelligence of each pesantren is needed so that this can be overcome so as not to remove the future generations of the nation that are honest, fair, and anti-corruption from our beloved homeland of Indonesia. More than that, pesantren has made many positive contributions to the development of the character of Indonesian society from time to time. 
Every human being must yearn for success in his life, success in work, success in academia, success in love, etc. To achieve the success of the Hereafter, Allah has written his tips in the Qur'an.

There are 9 keys to achieving the success that God has promised:

1. Bertaqwa, Al Muttaqin, Al Baqarah: 1-5 and Luqman: 5

People who will achieve the first success are those who have the character of godfearing in themselves, what are the characteristics of those who are called muttaqin. in verses 3-4 God describes their characteristics:
a. Believe in the Unseen
b. Establish Prayer
c. Love to share sustenance
d. Faith in the Teachings of Allah

2. Forming Mutually Helpful Communities towards success, Ali Imron: 104

3. Increase the positive activity, Al-A'raf: 8 and Annur: 102

4. Following and imitating the Prophet, AlA'raf: 157

5. Striving and Exerting Every Effort to the End, Attaubah: 88

6. Obeying God's Commandments and Laws, Annur: 51

7. Sharing to relatives and relatives, Ar-rum: 38

8. Stay away from the miser, Al Hasyr: 9, Attaghabun: 16

9. Decisive Against Infidels, Al Mujadilah: 22 The effect of sin on the fortune of a servant Sin committed by someone can affect the provision that God gives him. God withholds the sustenance of those who commit immorality. Allah subhaanahu wa ta'aala said:

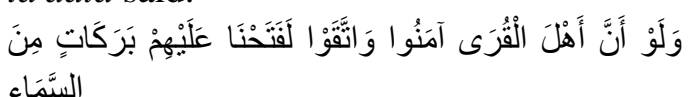

"If the inhabitants of the countries of faith and pious, surely we will bestow upon them the blessings of heaven and earth." (Surat al-A'raf: 96).

\section{CONCLUSION}

Ghasab is the control of other people's property arbitrarily or forcibly without rights, not in the sense of robbing or stealing, whether it's taking material possessions or taking advantage of an object. Ghasab can inhibit a person's success, explained in the Qur'an in Al-A'raf: 8 and Annur: 102 ie Increase positive activities, ghasab (negative) including milkiyyah violations that often occur in pesantren borrowing other people's goods without the permission of their owners this behavior in the long run will develop into theft. This is what will reduce the quality of scholars in the present, they are in terms of scientific expertise, but less in terms of blessing.

\section{REFERENCES}

[1] Ahmad Tafsir. 1992. Ilmu Pendidikan dalam Perspektif Islam. Bandug. PT Remaja Rosdakarya.

[2] Tim Dosen Fakultas Tarbiyah UIN Maulana Malik Ibrahim Malang. 2009. Pendidikan Islam Dari Paradigma Klasik Hingga Kontemporer. Malang: UIN-Malang

[3] Abdul Azis Dahlan, dkk., Ensiklopedi Hukum Islam, Syamsuddin Abu Abdillah. 2010. Terjemah Fathul Qarib, Penerjemah: Abu H.F Ramadhan. Surabaya: Mutiara Ilmu.

[4] Departemen Agama Republik Indonesia.1993. Al Quran dan Terjemah. Semarang: CV. ALWAAH.

[5] Ahmad Mustafa Al-Maraghi.1989. Terjemah Tafsir Al-Maraghi Juz II. Semarang: PT. Karya Toha Putra.

[6] Al Hafizh Ibnu Hajar al Asqalani. 2012. Terjemah Lengkap Bulughul Maram. Jakarta: Akbar Media.

[7] Mujamil Qomar, Pesantren Dari Transformasi Metodologi Menuju Demokratisasi Institusi, (Jakarta: Erlangga, tt).

[8] Nurcholish Madjid. 1997. Bilik-Bilik Pesantren Sebuah Potret Perjalanan. Jakarta: Paramadina.

[9] Yuniarso Kwartono,dkk. 2006. Mengasuh Santriwati: Peranan Pesantren Sebagai Penjaga Tradisi.Semarang: INDO Print.

[10] Rachmat Djatnika. 1992. Sistem Ethika Islam (Akhlak Mulia). Jakarta: Pustaka Panjimas. 
[11] Sidi Gazalba. 1981. Sistematika Filsafat. Jakarta: Bulan Bintang.

[12] Ahmad Amin. 1993. Etika (Ilmu Akhlak). Jakarta: Bulan Bintang. 